\title{
Defensive Surgery - a New Under-Recognized Reality among Surgeons?
}

\author{
Bogdan SOCEA' ${ }^{2}$, Ovidiu Gabriel BRATU², Alexandru Constantin CARAP', Tiberiu Paul NEAGU³, Dumitru
} Cristinel BADIU ${ }^{4}$, Dan Nicolae PADURARU ${ }^{5}$, Mihai DIMITRIU ${ }^{6}$, Vlad Denis CONSTANTIN

\begin{abstract}
In recent years, the number of medical litigations is increasing and defensive medicine becomes a widespread approach among physicians all over the world.

Defensive behavior of physicians is more common in scheduled, elective, compared to emergency medical services. The immediate direct consequences of this defensive behavior are found in the increase of costs (additional investigations) and the increase of waiting time for certain procedures and interventions (repeated postponements). Difficult and uncomfortable to admit that it exists, but defensive behavior is a reality. It raises numerous and complex ethical issues, and the goal of health policies should be to reduce this phenomenon.
\end{abstract}

Keywords: defensive medicine, defensive surgery, medical litigations.

\section{Rezumat}

În ultimii ani, numărul litigiilor medicale este în creștere, iar medicina defensivă a devenit o practică larg răspândită printre medicii din toată lumea.

Comportamentul defensiv al medicilor este constatat mai frecvent la intervențiile programate, elective, comparativ cu serviciile medicale de urgență. Consecințele directe imediate ale acestui comportament sunt creșterea costurilor (investigații suplimentare) și creșterea timpului de așteptare pentru anumite proceduri și intervenții (amânări, reprogramări).

Dificil și incomod de recunoscut, dar comportamentul defensiv este o realitate. Acesta ridică probleme etice numeroase și complexe, iar scopul politicilor de sănătate ar trebui să fie acela de a reduce acest fenomen.

Cuvinte cheie: medicină defensivă, chirurgie defensivă, litigii medicale.

\footnotetext{
1 Department of Surgery, "Sf. Pantelimon" Emergency Clinical Hospital, "Carol Davila" University of Medicine and Pharmacy, Bucharest, Romania

2 Department of Urology, Central Clinical Military Hospital, "Carol Davila" University of Medicine and Pharmacy, Bucharest, Romania

${ }^{3}$ Department of Plastic Surgery and Reconstructive Microsurgery, Emergency Clinical Hospital of Bucharest, "Carol Davila" University of Medicine and Pharmacy, Romania

${ }^{4}$ Department of Surgery, "Bagdasar-Arseni" Emergency Clinical Hospital, "Carol Davila" University of Medicine and Pharmacy, Bucharest, Romania

${ }^{5}$ Department Surgery, Emergency University Hospital, „Carol Davila" University of Medicine and Pharmacy, Bucharest, Romania

${ }^{6}$ Department of Obstetrics and Gynecology, "Sf. Pantelimon” Emergency Clinical Hospital, „Carol Davila" University of Medicine and Pharmacy, Bucharest, Romania
}

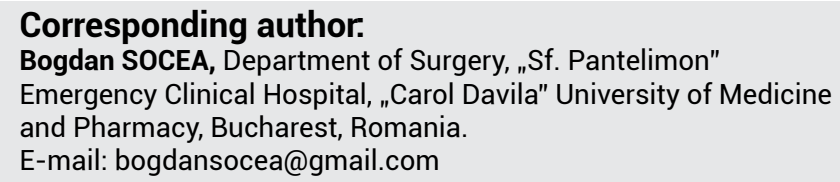

Corresponding author.

Bogdan SOCEA, Department of Surgery, "Sf. Pantelimon" Emergency Clinical Hospital, „Carol Davila” University of Medicine and Pharmacy, Bucharest, Romania.

E-mail: bogdansocea@gmail.com 


\section{INTRODUCTION}

Defensive medicine is a widespread approach among physicians all over the world. Defensive medicine is defined either by ordering of extra-investigations, tests or procedures (assurance behavior), or by avoidance of high-risk patients or procedures (avoidance behavior), for the purpose of reducing the risks of being accused for malpractice ${ }^{1,2}$. Defensive medicine is characterized as the deviation of the medical behavior from medical protocols and recognized guidelines.

In recent years, the number of medical litigations is increasing, especially in developed countries. With these, the defensive behavior of the doctors also appeared as a defense reaction. The relationship between the number of medical disputes and the defensive behavior seems to be directly proportional. Specialties and surgical procedures are more prone to risks, the surgeon being considered totally and often solely responsible for the evolution of the patient ${ }^{3}$.

The pressure on the surgeons became much greater, and the threats of any subsequent litigation could influence their judgment.

\section{DISCUSSION}

The immediate direct consequences of this defensive behavior are found in the increase of costs (additional investigations) and the increase of waiting time for certain procedures and interventions (repeated postponements), which can lead to aggravation of diseases, complications and even deaths during the waiting period, redirecting patients to others hospitals, increasing the length of hospitalization. All these consequences have a negative impact on healthcare.

The inappropriate ordering of invasive procedures exposes patients to unnecessary risks, while the avoidance of high-risk patients reduces their access to medical services ${ }^{4}$.

Defensive behavior of physicians is more common in scheduled, elective, compared to emergency medical services. In elective surgery the main advantage is the patient-surgeon relationship. The surgical team knows the patient, his status, had plenty of time to analyze the case, acknowledge a treatment plan, agree on the type of surgical procedure. Also, elective patients are prepared to postpone procedures, to refuse them for different reasons, or to redirect them to other hospitals, such as those with an emergency profile. Scheduled/elective patients go through a triage process, so that severe cases, with severe comorbidities, which are expected to have a complicated evolution, can be postponed, redirected and refused.

The situation is quite different in emergency conditions. Emergency and after-hour surgery can mean a patient that has hemorrhage risk, unprepared colon, mechanical and with antibiotics, exposes the patient to bacteria and the risk of post operator infection, anastomotic leakage, peritonitis, sepsis, wound complications; a more stressful environment for both the patient and the operating team ${ }^{5}$. The short time does not offer a gap for a wide analysis and the urgent situation no longer allows postponement or refusal of the surgical or medical act. In these situations, most of the times, the surgeon is no longer able to choose.

Personalized medicine is a new trend that has emerged in medical practice in recent years, and an unofficial form of that is the defensive medicine. For instance, unnecessary biopsies may be performed by physicians who concern of developing of malignant lesions near or at the site of a benign lesion and this situation is considered a form of malpractice called defensive medicine $^{6}$. Another well known example is that of defensive cesarean section (C-section), that had become a worldwide spread practice in developed countries and Romania $^{7,8}$. Defensive cesarean is defined as a cesarean delivery recommended by the doctor in absence of any clear medical indication to avoid possible litigation or a possible accusation of malpractice ${ }^{9}$.

The attitude of the various surgeons towards the threat of the litigations is different. On the one hand, there are supporters of the opinion that these disputes are justified, as a form of justice and represent a feedback that maintains the quality of healthcare. On the other hand, there are surgeons that have a more negative attitude, associated with negative emotions such as fear, stress, anger and low self-confidence ${ }^{10}$.

Furthermore, surgeons' attitudes differ for litigation which they perceive as ,justified" (when they made a mistake/negligence), versus litigation which they perceive "unjustified”, for example following a complication in spite of their correct treatment and attitude. The majority of malpractice litigation cases can be seen as „unjustified” since they are finally unconfirmed in justice $^{11}$.

In US, major medical errors reported by surgeons are strongly related to a surgeon's degree of burnout and their mental quality of life ${ }^{12}$. The problems of medical errors related to fatigue and burn-out syndrome seem to be more serious for the surgical specialties and interventional procedures, even if we talk about general 
surgeons, or gynecologists, urology surgeons, orthopedics or endoscopists ${ }^{13}$.

There are published studies showing that defensive medicine is common among residents ${ }^{14}$ and that sometimes senior surgeons encourage and teach young people to have a defensive attitude as a preferred attitude, which puts you at ease ${ }^{15}$.

\section{CONCLUSIONS}

Difficult and uncomfortable to admit that it exists, but defensive behavior is a reality. It raises numerous and complex ethical issues, and the goal of health policies should be to reduce this phenomenon.

The duty of physicians is to help patients as quickly, better and more correctly as possible. But can we judge the surgeons who are afraid that they may be dragged

\section{References}

1. Renkema E, Ahaus K, Broekhuis M, Tims M. Triggers of defensive medical behaviours: a cross-sectional study among physicians in the Netherlands. BMJ Open. 2019 Jun 25;9(6):e025108. doi: 10.1136/bmjopen-2018-025108.

2. Panella M, Rinaldi C, Leigheb F, et al. Prevalence and costs of defensive medicine: a national survey of Italian physicians. J Health Serv Res Policy 2017;22:211-7.

3. Spinu DA, Oprea I, Bodean O, Socea B, Diaconu C, Mischianu D, Marcu D, Bratu OG. Urological malpractice. Modern Medicine 2018;25(2): 65-8;

4. Studdert DM, Mello MM, Sage WM, et al. Defensive medicine among high-risk specialist physicians in a volatile malpractice environment. JAMA 2005;293:2609-17.

5. Socea B, Halau O, Bratu OG, Carap AC, Neagu TP, Badiu DC, Constantin VD. Is there an increased complications rate in after-hours colorectal surgery? Modern Medicine 2019;26(2):4749.

6. Toraldo DM, Vergari U, Toraldo M. Medical malpractice, defensive medicine and role of the "media" in Italy. Multidiscip Respir Med 2015;10:12

7. Viezuina R, Al Azawi A, Socea B, Navolan D, Davitoiu B, Bohiltea $R$. Does the defensive cesarean hide many elective cesareans sections? Proceedings of the 13th Conference of the Romanian-German Society of Obstetrics and Gynecology, Timișoara, 2017; ISBN 978-88-95922-95-9: 112-115.

8. Dimitriu M, Socea B, Ples L, Gheorghiu DC, Gheorghiu N, Neacsu A, Cirstoveanu CG, Bacalbasa N, Furau CG, Furau GO, Banacu M, Ionescu CA. Robson criteria for cesarean section-an imperative into time- and resources-consuming litigations, even when they have acted correctly and with good intentions but the patient's evolution has been complicated?

Managers of health policies should honestly recognize the existence of these situations and try to strengthen the position of surgeons by protecting them. The solution could come from better malpractice assurances.

Compliance with ethics requirements: The authors declare no conflict of interest regarding this article. The authors declare that all the procedures and experiments of this study respect the ethical standards in the Helsinki Declaration of 1975, as revised in 2008(5), as well as the national law. Informed consent was obtained from all the patients included in the study.

and emergent necessity in romanian obstetrics. Rev Chim (Bucharest) 2019;70(3):1058-1061.

9. Călin D, Socea B, Constantin VD, Gheorghiu DC, Ciobanu AM, Bacalbașa N, Gheorghiu N, Ples L, Cîrstoveanu C. Defensive caesarean section - a reality in Romania. Proceedings of the XIIIth Conference on Bioethics (Iasi, Romania, 8-10 November 2018), Filodiritto Editori 2019; ISBN 978-88-85813-58-8: 337-340.

10. Ortashi $\mathrm{O}$, Virdee J, Hassan R, et al. The practice of defensive medicine among hospital doctors in the United Kingdom. BMC Med Ethics 2013;14:42.

11. Jena AB, Chandra A, Lakdawalla $D$, et al. Outcomes of medical malpractice litigation against US physicians. Arch Intern Med 2012;172:892-4

12. Shanafelt TD, Balch CM, Bechamps G, Russell T, Dyrbye L, Satele D, Collicott P, Novotny PJ, Sloan J, Freischlag J. Burnout and medical errors among American surgeons. Ann Surg 2010;251(6):995-1000. doi: 10.1097/SLA.0b013e3181bfdab3.

13. Socea B, Bobic S, Moculescu C, Nica AA, Diaconu CC, Constantin VD, Baleanu VD, Tenea Cojan TS. Surgical malpractice in relation to long calls. Proceedings of the XIIIth Conference on Bioethics (lasi, Romania, 8-10 November 2018), Filodiritto Editori 2019; ISBN 978-88-85813-58-8: 317-319.

14. Passmore K, Leung WC. Defensive practice among psychiatrists: a questionnaire survey. Postgrad Med J 2002;78:671-3.

15. O'Leary KJ, Choi J, Watson K, et al. Medical students' and residents' clinical and educational experiences with defensive medicine. Acad Med 2012;87:142-8. 
